\title{
The Efficiency of Fiscal Incentive in Municipalities With Lower Human Development Indices: The Case of Maranhão
}

\author{
Fernando Silva Lima ${ }^{1}$, Mariano Yoshitake ${ }^{2} \&$ Marcia Helena Andrade ${ }^{3}$ \\ ${ }^{1}$ Federal Institute of Education, Science and Technology of Maranhão-Bacabal Campus, Avenida Governador João \\ Alberto, Bacabal, Brazil \\ ${ }^{2}$ Ceuma University, Teaching Association, São Luís, Brazil \\ ${ }^{3}$ Universidade Estadual de Goiás-Campus Jaraguá, Jaraguá, Brazil \\ Correspondence: Fernando Silva Lima, Federal Institute of Education, Science and Technology of \\ Maranhão-Bacabal Campus, Avenida Governador João Alberto, CEP 65.700-000, Areal Neighborhood, Bacabal, \\ Brazil.
}

Received: July 9, 2018

doi:10.5430/ijba.v9n5p62
Accepted: July 29, 2018

Online Published: August 17, 2018

URL: https://doi.org/10.5430/ijba.v9n5p62

\begin{abstract}
The objective of this article is to verify if the fiscal incentive had impact on the generation of employment in the municipalities that have the lowest IDH indices of the state of Maranhão. To this end, the study analyzes the development of employment generation during the granting of the fiscal incentive in Maranhão through the Meso-regions between 2010 and 2016. The specific objectives are: to identify the criteria established for granting the fiscal incentive; compare the number of jobs generated with the number of companies that benefited from the tax incentive; to verify the evolution of the jobs generated in each mesoregion and to know the economic activities that generate more jobs in the state. The problem of this research is: what are the impacts of fiscal incentives on employment generation in municipalities with the lowest IDH indices in Maranhão. It considers the methodology of this study, a field research, but of quantitative-descriptive character. Among the results, it was identified that the fiscal incentive had no impact on job creation in the Meso-regions that have the lowest IDH indices in the state of Maranhão between 2010 and 2016.
\end{abstract}

Keywords: fiscal incentive, regional development, poverty

\section{Introduction}

The state of Maranhão is one of the poorest in the northeastern region and in Brazil, therefore, it has great deficiencies and few social indicators that influence income and economic structure, aggravated by the poor supply of public services (CARVALHO, 2015, 24).

It is understood that low social indicators are related to the large number of people living in extreme poverty that correspond to $25.8 \%$ of the total of 1.7 million people (IBGE, 2010).

It is understood that in some cases, due to the low rate of job creation, the income of these people is equivalent to $\mathrm{R}$ $\$ 70$ in which they are guaranteed by the family scholarship program (MDS, 2014).

Thus, in 2010, the Government of Maranhão created the "Promaranhão" program, but in 2015 the state revoked it and created the "more companies", with the aim of diversifying the industrial matrix, forming industrial densities in the economic regions and integrating productive chains essential to the development and generation of jobs and income in the state.

To ensure the diversification of the industry in the state, the government proposed a reduction of up to $95 \%$ (ninety-five percent) of the value of the tax on operations related to the movement of goods and on services of interstate, intermunicipal and communication services (ICMS ) for 15 years, but, according to Law No. 10,690 of September 26, 2017, the government extends to 20 years and inclusive, includes in this reduction percentage (95\%), Municipality of the Integrated Development Network (RIDE), or cities that belong to a metropolis.

It is understood that, investors are entitled in the referred reduction of ICMS (95\%) may prefer to establish in one of the 30 (thirty) municipalities of lower IDH, or in municipalities belonging to metropolitan regions. 
In view of this, it is conceived that the benefit of reduction of ICMS may favor the metropolitan areas of Maranhão, instead, from other regions, even investors can attribute municipalities with low IDH due to the lack of infrastructure in the areas of basic sanitation, health, safety and workmanship.

A research carried out on tax incentives in the state of Tocantins by Rodrigues and Araújo (2016), it was emphasized that investing in infrastructure, logistics potential and seeking the industry for the state of preference those that use the local raw material and the qualification of the hand of can attract investors.

Therefore, it is a concept that, not always, the reduction of a tax is a viable alternative to stimulate the economic development of a region, since, Reese (2005) affirms that in the last two decades, academics and evaluators have made a series of recommendations to reformulate local economic development policies and at no time, recommended the use of tax reduction.

In this sense, it can be seen that in Maranhão the reduction of taxes has come from tax incentives and that according to Ottati, (2013), has not worked, therefore, some municipalities grew economically, but there was not in the same proportion, progress in the quality of people's lives.

It is understood that, in some cases, the quality of life of the individuals may be associated with a lack of job generation and income. Therefore, the guiding question of this article is: what are the impacts of the fiscal incentive in the generation of employment in the municipalities that possess the lowest IDH in Maranhão and Brazil?

In view of the above, this article has as general objective to verify if the fiscal incentive had an impact on employment in the municipalities that have the lowest IDH indices in the state of Maranhão. Therefore, the study analyzes the development of employment generation during the concession of the fiscal incentive in Maranhão through the Meso-regions between 2010 and 2016.

\section{The Fiscal Incentive Policy}

Over the years, tax incentives have been the object of study where researchers seek answers to the hypotheses related to the impacts on the local and regional economy, especially in what refers to the generation of employment and income. For this reason, Barbosa and Moretto (1998) affirm that the first employment-oriented social protection policies comprise the years 1883 and 1940.

It is observed that the public power has created fiscal incentives for the generation of employment and income to develop in a positive way to the initial demands, but for Laurias $(2013,54)$ "it is necessary a study of public employment policies, aimed at attempts to eradicate or control unemployment. "

For this to happen, public policies for generating employment and income necessarily need to be efficient and effective in order to promote the sustainability of the state, including the less developed regions.

The Maranhense Institute for Socioeconomic and Cartographic Studies (IMESC) carried out an analytical study of the labor market in the state between the years 2000 and 2013 in 2013. This study showed a development of formalization of employment and an increase in the level of education of the population in formal employees.

In this context, the IMESC (2013) since the international financial crisis of 2008 and 2009, especially in mid-2011, Brazil has entered a much less favorable context and, in this scenario, the economy of Maranhão, one of the most vulnerable to the international cycle, began to develop slowly.

As a result, the state of Maranhão revoked Law No. 9,121 of March 4, 2010 known as "promaranhão" and created Law No. 10,259 of June 16, 2015 called "more companies" that broadens and improves the conditions for granting incentive in the state so that new ventures among these concessions, the reduction of ICMS rate for companies opting for Simple as well as micro and small businesses of Maranhão including, allowing them to participate in government bids and simplification and exemption of environmental licensing for family farmers (Maranhão, 2015).

According to Campanelli (2010, p. 79), "fiscal incentives are mere instruments for other state competencies to achieve their results, oblivious to the merely taxpayers."

In this sense, the state reduces the tax burden, renounces part of the ICMS in order to develop specific sectors and stimulate the economy. However, the massive fiscal waiver practiced by the states can result in the federal government not being able to promote a policy of development, since the abdication of collection, in high magnitude, can make investments that generate employment impossible (MELO, 1996).

What is important is that the process of economic growth, through fiscal incentives, starts when the state renounces part of this revenue, but, in contrast, local and regional development in the scope of employment and income generation comes short or long term. 
According to the Ministry of National Integration - MI (2011), the tax incentives "... have the objective of generating employment and income and stimulating the economic and social development of these regions."

According to Lima and Lima (2010, page 568a), the fiscal incentive diversify productive chains, increase future tax collection, consolidate productive agglomerations in their territories and generate jobs and income, so that the future growth of the economy becomes less dependent on the granting of these incentives.

The concession of this benefit occurs to the extent that the companies interested in the "more companies" program sign the agreement (TARE) with the state government.

Whereas, the "more companies" program grants a presumed credit on the value of the monthly ICMS calculated, in the cases of implantation, expansion, modernization, re-location and reactivation, and deferral in periods and proportions (MARANHÃO, Law No. 10,259 of 16 of June 2015).

The presumed credit is offered by the state of Maranhão to companies encouraged by means of ICMS reversal on the exits of merchandise.

These benefits, in a certain way, seek to develop the cities of Maranhão considered worse in the statistical survey in relation to the IDH, since Law No. 10,259 of June 16, 2015 considers as priorities for the economic development of the state.

However, it is understood that the fiscal incentive policy has focused on economic activities, rather than municipalities, especially those with the worst IDH, and thus, the programs end up being similar to those offered in other states with better infrastructure, among which stand out

The priority given to the incentive granted to investment projects that use raw materials and local inputs, to exploit productive potential of the state, develop activities with a high technological content and have a high germinative power in relation to employment besides considering the volume of investment to be (LIMA AND LIMA, 2010, pp. $568 b)$.

\section{Research Methodology}

This article has as object of study the fiscal incentive policy in Maranhão. Due to the territorial extension of Maranhão, this study aimed to focus on mesoregions of the state, such as the center, east, west, north and south of Maranhão. Therefore, this study sought to analyze the regional development in the mesoregions, through fiscal incentives, between 2010 and 2016.

In order to identify the criteria established for granting the most recent tax incentive in the state, it was necessary to conduct a survey on the site of the State Treasury Secretariat (SEFAZ-MA) to identify and characterize the "more companies" program, the number of companies benefited by the incentive and number of municipalities with the lowest IDH in each mesoregion of the state and compare them. This preference consisted of the sample process for this study.

Then, a search was made on the site of the Ministry of Labor and Employment (MTE) on jobs generated and on economic activities in the state, but for that, a login and password was provided by the public agency and thus, it was possible to verify if the main economies evolved between 2010 and 2016 in each mesoregion.

When carrying out the procedure and collecting the information about the "more companies" program, on the companies benefited, on the numbers of municipalities with the worst IDH in each mesoregion, these were codified in the program Microsoft Excel and later transformed into graph.

However, on the evolution of jobs generated by mesoregions and economic activities, it was necessary to use the statistics to verify the absolute variation between the years 2010 and 2016. The variation treated in this study is the one in which it can be presented under several forms: absolute, relative or relative of percentage. For that, only the coefficients of the absolute and relative variable of percentage were used, therefore, it is considered quantitative.

The absolute change will be called $(\Delta x)$ in which the difference between the year 2010 that will be considered the final value and 2016 will be considered as the initial value, where: $\Delta x=\mathrm{Xf}-\mathrm{Xi}$.

On what:

$\Delta \mathrm{x}=$ means each mesoregion of the state;

$\mathrm{Xf}=$ means the number of jobs generated in the year 2010 in each meso-region;

$\mathrm{Xi}=$ means the quantity of jobs generated in the year 2016 in each meso-region.

In this study we intend to demonstrate from the equation that if the absolute variation is: 
- Positive $(\Delta x>0)$, $x$ increased.

- Null $(\Delta x=0)$, $x$ remained unchanged.

- Negative $(\Delta x<0)$, $x$ decreased.

The relative percentage variation is a different form of representing the relative variation of $\mathrm{x}$ :

$\Delta \mathrm{x}=(\mathrm{Xf} / \mathrm{Xi})-1$

This is the most frequent and intuitive way to represent a variation in a laboratory.

- If a quantity increases by $100 \%$ then it doubles;

- If a quantity decreases by $50 \%$ then it is halved.

This formula, in addition to being widely used by statisticians, is also widely used by the Ministry of Labor and Employment (MTE) to calculate the evolution of jobs and income in the country.

The method used usually followed the field research phases and without departing from the quantitative-descriptive focus.

\section{Summary of Maranhão "More Companies" Program}

According to the exploratory research carried out on SEFAZ-MA's official website. This incentive was created through Law 10,259, dated June 16, 2015, which establishes the program of industrial development and economic integration of the state of Maranhão "Mais Empresas", originating in the "promaranhão" program (Law No. 9,121, March 4 of 2010). The difference between the "more companies" program and the old "promaranhão" program is to increase the benefit and reduction of ICMS, as well as the extension of the period for the use of the incentive.

In relation to the criteria established by the Maranhão Government for the concession of the "more companies" program, the following preliminaries were established: investment volume; number of jobs generated; have links with regional production chains; purchase of inputs in the local market; adoption of social and environmental responsibility measures; be installed or have influence in the municipalities with the lowest IDH in the state (SEINC-MA, 2017).

To date, 53 companies have benefited from this program, including: 02 from Açailândia; 03 of Bacabeira; 02 of Balsas; 03 of Caxias; 02 of Codó; 01 of Davinópolis; 03 by Governor Edsison Lobão; 09 of Empress; 03 of Itapecuru Mirim; 01 of Miranda do Norte; 01 of Quarries; 01 by President Dultra; 01 of Fox; 01 of Santa Luzia do Parua; 17 of São Luís; 01 of Timon; 01 of Tuntum and 01 of Tutóia therefore, all are active. It should be noted that 02 companies closed their activities according to the cadastral situation made by CNPJ in the Brazilian Internal Revenue Portal, where 55 companies benefited from the "more companies" program (SEINC, 2017).

In addition, it was noted that almost $50 \%$ of the companies benefited by the tax incentive "more companies", are concentrated in São Luís and Imperatriz. Another factor observed is that up to the present time, municipalities cited in the list of 30 municipalities with the lowest IDH in the state were not found companies encouraged in these cities.

\section{Analysis of the Influence of Tax Incentives in the Municipalities With the Highest IDH of Maranhão}

In view of the fact that fiscal incentives are concentrated in municipalities located near cities with low IDH, this study sought to analyze the data through the mesoregions of the state.

I. Comparison between the number of incentive companies and the number of poor municipalities in Maranhão per meso-region

The first perception was about the center of Maranhão, where it was observed that it is a region quite affected by the lack of regional development, since the poorest municipalities of the federation are located in this region. See Figure 1. 


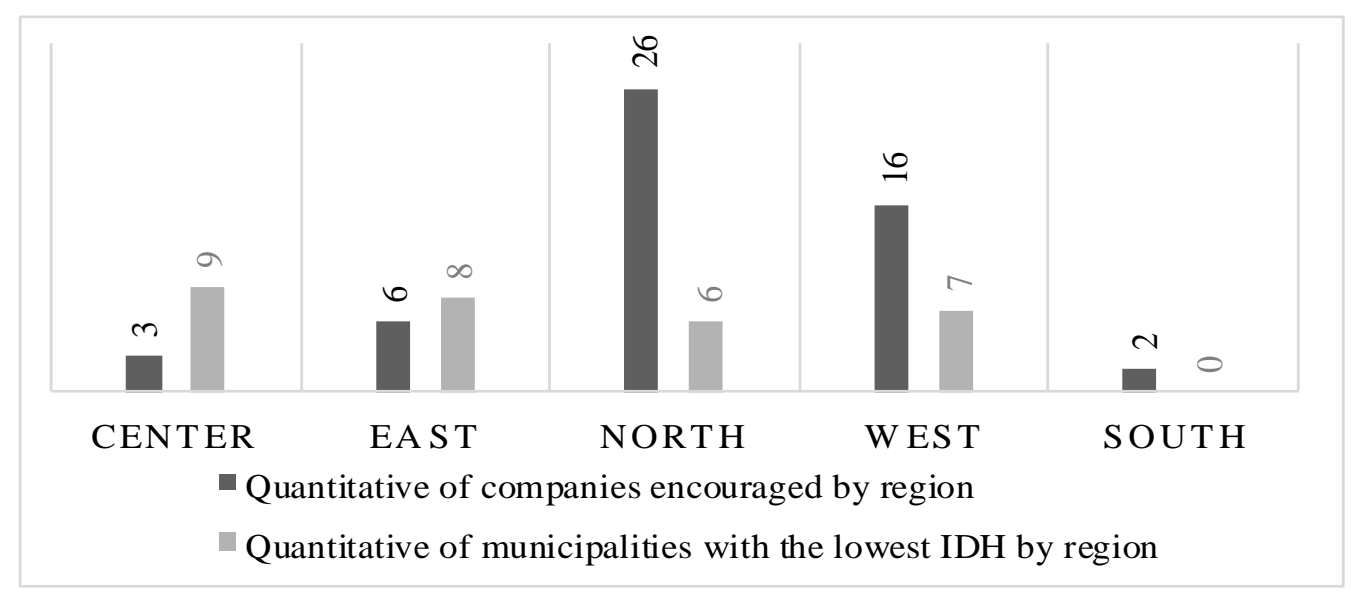

Figure 1. Municipalities with low IDH and companies encouraged in each mesoregion

Source: Seinc-MA and Sefaz-MA, 2017. (Data organized by the authors).

When analyzing graph 01, it can be observed that in the mesoregion of Maranhão, there are three companies that benefit from the "more companies" program located in the municipalities: Tuntum, Pedreiras and Presidente Dultra; However, in this region there are the highest number of municipalities with the lowest IDH, and it should be one of the regions that should benefit most in line with their reality, it is evident that the poorest municipalities have not benefited. mapping the mesoregions and municipalities that most need the incentive.

It should be noted that if the "more companies" program carried out a control and evaluation system, it would detect such a situation, the implementation of a performance and performance evaluation would allow a detailed visualization as well as the identification of the results produced by the incentive provided by the government.

The scenario must be analyzed and reversed so that the program will in fact produce positive results and reach its objective, proof of this assertion is the situation of the South Maranhense region that has a quantitative equivalent to zero, that is, there is no mesoregion in the municipalities with Low IDH to be benefited by the program and yet there are two municipalities that are benefited, such an incentive could be making the difference in the municipalities they really need as the case of the Maranhense Center, being visible the need to reallocate the incentives to poor municipalities.

It should be noted that the companies located in the center of Maranhão tend to benefit from a reduction of up to 95\% of the presumed ICMS credit due to being located near the municipalities: Arame; Fernando Falcão; Itaipava do Grajaú; Jenipapo dos Vieiras; Santa Filomena; Santana Do Maranhão; São Raimundo Do Doca Bezerra; They are Roberto and Satubinha. All are considered one of the worst cities in relation to the IDH.

Even when it comes to companies, one factor that attracted attention during the investigation is that almost $50 \%$ of the incentive companies are concentrated in the northern region of the state, but in the center of Maranhão this percentage reaches almost $6 \%$.

According to figure 01, the northern Maranhão mesoregion is the one with the lowest number of poor municipalities; however, this region is the one that most includes incentivized companies, but when referring to the total of municipalities with lower IDH, it is noted that almost $30 \%$ of them are in the center and almost $27 \%$ of them in the eastern region of the state, which, in fact, was less benefited.

However, for Lynn (1980), the fact that the state fosters fiscal incentive policies produces specific effects for the development of the local industrial complex in which, for Peters (1986), it may be through the promotion of economic growth or local development, tax incentives directly impact citizens' lives.

However, it can be observed in Graph 01 that the fiscal incentives created in Maranhão were not consistent in the diversification and integration of economic development in the municipalities most affected by the low IDH, since in this study it demonstrates the disproportionality in the quantitative of the companies that benefit of incentives in each mesoregion compared to the poorest regions of the state.

Therefore, that in some cases, when the only alternative of the public power is the creation of tax incentives, as a suggestion, it would be interesting to grant companies benefits according to regions because, public government 
policies must respect the production capacity, local productive arrangements, and infrastructure conditions beyond that, qualify labor.

Given that, on the one hand, there is the fiscal incentive of the government and, on the other hand, industrialization that creates a peak of opportunities that it is not able to maintain after the implementation phase when this opportunity is greater than the demand of the workers (FURTADO, 2005).

II. Comparison of the evolution of jobs generated between the most incentivized and least incentivized regions

Table 2. Evolution of Jobs generated by mesoregions between 2010 and 2016

\begin{tabular}{lrrrrr}
\hline MESOREGIONS & \multicolumn{2}{l}{2010} & 2016 & $\begin{array}{l}\text { ABSOLUTE } \\
\text { VARIATION }\end{array}$ & \multicolumn{2}{c}{$\begin{array}{l}\text { RELATIVE } \\
\text { VARIATION }\end{array}$} \\
\hline Center Maranhense & 7388 & 7355 & -33 & $-0,45 \%$ \\
North Maranhense & 102133 & 77905 & -24228 & $-23,72 \%$ \\
West Maranhense & 32563 & 29156 & -3407 & $-10,46 \%$ \\
East Maranhense & 13741 & 11035 & -2706 & $-19,69 \%$ \\
South Maranhense & 24259 & 11115 & -13144 & $-54,18 \%$ \\
\hline
\end{tabular}

Source: Rais, 2010 and 2016. (Data organized by the authors).

In relation to the evolution of the jobs generated between the more incentivized and less incentivized mesoregions, it can be noticed that the regions known as south and north of Maranhão were the ones that had the lowest growth in job creation, being $-54.18 \%$ and $-23,72 \%$, respectively.

Another intriguing factor is that before the creation of fiscal incentives policies, these regions (south and north) had a superior development compared to the number of jobs generated in 2016, therefore, they presented an absolute negative change of -13144 and - 24228, respectively.

It is noteworthy that the northern mesoregion of the state was the one that received more companies encouraged, however, this region has the lowest number of municipalities with the worst IDH.

It is understood that the IDH issue, makes the state less attractive in the eyes of productive investments because companies do not want to see their "mark" linked to negative aspects and external standards of sustainable development (NASCIMENTO E MORAIS, 2009, p, 27a).

It should be noted that the mesoregion of southern Maranhão is the one with the lowest evolution, reaching the highest absolute negative variation (-54.18\%), however, it has incentive companies, but in this region there are no municipalities with the worst IDH.

According to Nascimento and Morais (2009, page 27b) this reflects the ways in which the economy is structured, with extreme inequality in the distribution of income; in the pattern of employment of the workforce with strong rates of underemployment and informality due to low standards of professional qualification, this lack of specialization is responsible for the low productivity and poor quality of the services produced and it is not because there are no places qualified for teaching- learning, what happens is the inaccessibility of training centers, such as public universities for the majority of the population.

However, Table 02 shows the central region of Maranhão, in spite of having the largest number of municipalities with the worst IDH in the state and in Brazil and a low number of companies encouraged, was the region with the least negative impact in relation to the generation of jobs $(-0.45 \%)$.

It is pertinent to emphasize that the North Maranhense mesoregion even though receiving the majority of the incentive percentage of the "more company" program demonstrated an unexpected result against the incentive applied in the companies, it was expected that if the companies received the benefits consequently the operational cycle, the financial flow and the number of jobs would increase, which did not occur in the latter case, demonstrating the greatest reduction in job generation, as we can see in the Table above.

It is pertinent to show that in addition to the expectations the Centro Maranhense region, even obtaining little incentive as elucidated in Table 02, remained practically in balance in the generation of jobs in relation to the other regions, presenting the lowest reduction number. In view of the data, all the mesoregions presented a reduction in the generation of jobs, it was not only a specific mesoregion that could be affected by the Brazilian economic scenario in crisis. 
III. Identification of the main economic activity in relation to the number of jobs generated by meso regions

Table 3. Economic activity sector responsible for generating employment

\begin{tabular}{|c|c|c|c|c|c|}
\hline MESOREGIONS & SECTOR & 2010 & 2016 & $\begin{array}{l}\text { ABSOLUTE } \\
\text { VARIATION }\end{array}$ & $\begin{array}{l}\text { RELATIVE } \\
\text { VARIATION }\end{array}$ \\
\hline Center maranhense & Services & 807 & 1409 & 602 & $74,60 \%$ \\
\hline Center maranhense & Industry & 608 & 942 & 334 & $54,93 \%$ \\
\hline Center maranhense & $\begin{array}{l}\text { Building } \\
\text { Construction }\end{array}$ & 462 & 551 & 89 & $19,26 \%$ \\
\hline Center maranhense & Trade & 3220 & 3213 & -7 & $-0,22 \%$ \\
\hline Center maranhense & farming & 2291 & 1240 & -1051 & $-45,88 \%$ \\
\hline East maranhense & Services & 1052 & 1561 & 509 & $48,38 \%$ \\
\hline East maranhense & Industry & 2086 & 2583 & 497 & $23,83 \%$ \\
\hline East maranhense & Trade & 4150 & 4426 & 276 & $6,65 \%$ \\
\hline East maranhense & $\begin{array}{l}\text { Building } \\
\text { Construction }\end{array}$ & 2265 & 1640 & -625 & $-27,59 \%$ \\
\hline East maranhense & farming & 4188 & 825 & -3363 & $-80,30 \%$ \\
\hline North maranhense & farming & 467 & 522 & 55 & $11,78 \%$ \\
\hline North maranhense & Services & 36103 & 35313 & -790 & $-2,19 \%$ \\
\hline North maranhense & Trade & 24585 & 19133 & -5452 & $-22,18 \%$ \\
\hline North maranhense & Industry & 6643 & 4678 & -1965 & $-29,58 \%$ \\
\hline North maranhense & $\begin{array}{l}\text { Building } \\
\text { Construction }\end{array}$ & 34335 & 18259 & -16076 & $-46,82 \%$ \\
\hline West maranhense & Services & 5017 & 8003 & 2986 & $59,52 \%$ \\
\hline West maranhense & Trade & 10124 & 10421 & 297 & $2,93 \%$ \\
\hline West maranhense & Industry & 4707 & 3110 & -1597 & $-33,93 \%$ \\
\hline West maranhense & $\begin{array}{l}\text { Building } \\
\text { Construction }\end{array}$ & 5203 & 3172 & -2031 & $-39,04 \%$ \\
\hline West maranhense & farming & 7512 & 4450 & -3062 & $-40,76 \%$ \\
\hline South maranhense & Services & 1510 & 1417 & -93 & $-6,16 \%$ \\
\hline South maranhense & Trade & 3214 & 2699 & -515 & $-16,02 \%$ \\
\hline South maranhense & farming & 6409 & 5103 & -1306 & $-20,38 \%$ \\
\hline South maranhense & Industry & 3439 & 1248 & -2191 & $-63,71 \%$ \\
\hline South maranhense & $\begin{array}{l}\text { Building } \\
\text { Construction }\end{array}$ & 9687 & 648 & -9039 & $-93,31 \%$ \\
\hline
\end{tabular}

Source: Rais, 2010 and 2016. (Data organized by the authors).

Of the five mesoregions analyzed, the South and North Maranhense were the ones that presented the most reduction of generation in all sectors of economic activity, and among the other mesoregion the service sector was the one that most impelled the generation of jobs with the exception of the North Maranhense mesoregion that the sector that had the most propellant was that of Agropecuária, as can be observed in Table 03. When analyzed the sector that had more fall in the generation of jobs, the sector of Agropecuária was the one that was most affected in the mesoregions of Central, East and West Maranhense, followed of the Civil Construction sector in the North and South Maranhense mesoregions.

However, table 03 shows that the central region of Maranhão had a reduced number of companies, although it was the smallest negative impact, because this region was the one that most developed economically reaching the first place in the service sector with the variation of $74,60 \%$, reaching $54.93 \%$ of the ranking in the industrial sector, and finally, the civil construction sector grew $19.26 \%$. 
It is noteworthy that the "more companies" tax incentive was created to strengthen the industry in Maranhão, but in the Maranhão central region the sector that presents a continuous growth is the service sector.

Regarding tax incentives and industries, it is observed that the northern mesoregion of the state was the one that received incentive companies, however, they presented a negative variation of $-29.58 \%$ in relation to 2010 and 2016 in this sector. Thus, it was identified that the fiscal incentive is not sufficient to develop this region, considering that the only one that grew economically in relation to 2010 and 2016, was the agricultural sector. Finally, the research shows that although the mesoregions of the south and west of Maranhão have a reduced number of industries, the region also suffered a reduction of generated jobs: $-63.71 \%$ and $-33.93 \%$, respectively.

The analyzed period from 2010 to 2016 was extremely timely and valid since it consisted of five years of analysis, the distribution of the mesoregions included all municipalities in the state of Maranhão, and the information was collected from reliable and reliable sources, thus enabling analysis and comparisons obtaining conclusive considerations on the subject.

\section{Conclusions}

Considering the problematic of this article, the impacts of the fiscal incentive in the generation of employment in the municipalities that have the lowest IDH of the state and in the Country, the research reveals that, the Maranhão government sought to improve the indicators of employment generation, with the reduction of the tax (ICMS); extended the term of the concession of this benefit and hopes to diversify the industrial matrix. Thus, it was noted that investors in the state have a preference to settle in São Luís and Imperatriz, to the detriment of regions with the lowest IDH. Such a situation suggests that the government needs to review the "more companies" program in order to promote fairness of opportunities and thus improve the indicators of employment and IDH in Maranhão. In addition, it is recommended to implement a performance and performance evaluation system in front of the implemented program, seeking to evaluate its efficiency and effectiveness.

Another point observed is that the industries had a negative impact on the generation of jobs in the north of Maranhão and the fiscal incentives were not enough to reverse the situation, since in this locality had the largest number of companies benefited. It was also observed that the regions with the lowest IDH have survived by the strong presence of the service sector and what is striking in this region is that this sector is not included in the policy of the "more companies" program, it also shows that in the center Maranhão, the fiscal incentive did not generate employment impact.

In fact, the present study was extremely relevant, initially contributing to a possible government analysis regarding the application of incentives to municipalities and companies, allowing effective and efficient application of the resource, thus achieving the objectives of the program, ensuring that companies that really need to be benefited and with that increase in the generation of jobs in the municipalities in all the sectors. The research represents an aid and alert to the public managers, evidencing that the municipalities that are in condition of poverty need incentives that are efficient, generating economic financial benefit for the company and social for the society. In this way, the study focuses on the public policies of the public entity, the economic and financial management of companies and social in the search for the reduction of poverty and job creation with the application of the program.

Finally, it was identified that the fiscal incentive had no impact on employment in the Meso-regions that have the lowest IDH indices in the state of Maranhão between 2010 and 2016.

As future studies, it is suggested to investigate the causes of the lack of job creation in the mesoregions of northern Maranhão and the lack of fiscal incentives and also a continuity of the present study, with other approaches and data for analysis.

\section{References}

Barbosa, A. De F., \& Moretto, A. (1998). Policies of Social Protection. ABET.

Brazil. (2017). Ministry of National Integration (MI). Tax breaks. Retrieved October 28, 2017, from http://www.mi.gov.br/apresentacao18

Brazil. (2017). Ministry of Social Development and Fight against Hunger. Matrix of social information. Retrieved July 4, 2017, from http://aplicacoes.mds.gov.br/sagi/portal/

Brazil. (2017, February). Decree No. 6,047. Establishes the National Policy for Regional Development-PNDR and makes other provisions. 
Campanelli, D.M. (2017). State tax incentives granted unilaterally and legal certainty. 2010, 193 p. Dissertation (Master in Law)-Pontifícia Universidade Católica de São Paulo (PUC-SP), São Paulo, 2010. Retrieved October 31, 2017, from http://www.dominiopublico.gov.br/download/teste/arqs/cp146881.pdf

Carvalho, F.C.de. (2015). Regional-territorial development policy and governance: A recent analysis of the state of Maranhão (Brazil). Thesis (doctorate)-Institute of Geosciences and Exact Sciences, Universidade Estadual Paulista. Retrieved May 23, 2017, from repositorio.unesp.br/bitstream/handle/11449/138539/000864210.pdf?sequence=1

Crespo, A.A. (1995). Easy statistics (13th ed.). São Paulo: Saraiva.

Gerhardt, T.E. (2009). The construction of the research. In Gerhardt, T.E. (Org.) \& Silveira, D.T. (Org.), Research Methods. Porto Alegre: Publisher of UFRGS.

Lakatos, E.M., \& Marconi, M.de.A. (2003). Fundamentals of scientific methodology (5th ed.). São Paulo: Atlas.

Laurias, N.C. (2013). Public Policies of Tax Incentives in Goiás: An Analysis on the Perspective of the Generation of Jobs. IPEA.

Lima, A.C.da.C., \& Lima, J.P.R. (2017). Local development programs in Northeastern Brazil: a preliminary assessment of the "fiscal war". Econ. soc. 2010, 19(3), 557-588. https://doi.org/10.1590/S0104-06182010000300006

Lynn, L.E. (1980). Designing public policy: A Casebook on the Role of Policy Analysis. Santa Monica, Calif. Goodyear.

Maranhão. (2010). Law No. 10,259 of June 16, 2015. Establishes the Industrial Development and Economic Integration Program of the State of Maranhão (MAIS EMPRESAS), repeals Law No. 9,121, dated March 4, 2010, and makes other provisions.

Maranhão. (2010). Law No. 9,121 of March 4, 2010. Creates the Incentive Program for Industrial and Technological Activities in the State of Maranhão (PROMARANHÃO).

Maranhão. (2013). Studies on the Contemporary Maranhense Economy. São Luís: IMESC.

Maranhão. (2017). Law No. 10,690, dated September 26, 2017. It establishes a system of taxation, in the scope of the Tax on Operations related to the Circulation of Goods and on the Provision of Interstate and Intermunicipal Transportation and Communication Services (ICMS).

Maranhão. (2017). Secretary of State for Industry, Commerce and Energy of Maranhão (SEINC/MA). Retrieved May 31, 2017, from http://www.seinc.ma.gov.br/

Melo, J.E.S. (1996). ICMS: theory and practice (2nd ed.). São Paulo: Dialectics.

Nascimento, A.T., \& Morais, M.A.F. (2009). The Maranhão in the rails of the advance? A study of the space-time transformations of Maranhão industry in capitalist society of flexible time. Article. Cad. Pesq., São Luís, v. 16, n. 3, ago./dez. Retrieved December 7, 2017, from http://www.periodicoseletronicos.ufma.br/index.php/cadernosdepesquisa/article/view/125/92

Ottati, A.M.A., \& Dos A. (2017). The dynamics and the regional developmental problems in the state of Maranhão. Thesis (PhD)-Postgraduate Program in Rural Development of the Faculty of Economic Sciences, Federal University of Rio Grande do Sul. Retrieved May 23, 2017, from https://www.lume.ufrgs.br/bitstream/handle/10183/72257/000883319.pdf?Sequence=1

Parente, E.A.De.M., \& Caribé, R. (1996). Commercial and financial mathematics: 145 exercises solved, 262 exercises proposed with answers, 99 tests of competitions and vestibular. São Paulo: FTD.

Peters, B.G. (1986). American public policy. Chatham-NJ: ChathamHouse. https://doi.org/10.1007/978-1-349-18388-3

Pochmann, M. (1998). Challenges and limits of employment policies in Brazil. Campinas, Mimeo.

Reese, L.A. (2017). The equity impacts of municipal tax incentives: leveling or tilting the playing field? annual meeting of the Southern Political Science Association, New Orleans, January, 2005. Retrieved May 23, 2017, from www.mml.org/pdf/tax.pdf

Rodrigues, W., \& Araújo, M.R.N. (2016, January/April). The policy of granting fiscal benefits in the state of Tocantins: what do institutional actors think?. Networks (St. Cruz Sul, online), 21(1), 103-120.

Spiegel, M.R. (1975). Statistics: summary of theory, 875 problems solved, 619 problems proposed. Translation by Pedro Cosentino. ed. rev. by Carlos José Pereira de Lucena. São Paulo: McGraw-Hill do Brasil. 